\title{
Phosphorus Placement Effects on Phosphorous Recovery Efficiency and Grain Yield of Wheat under No-Tillage in the Humid Pampas of Argentina
}

\author{
Pablo Andrés Barbieri, ${ }^{1,2}$ Hernán René Sainz Rozas, ${ }^{1,2,3}$ \\ Fernanda Covacevich, ${ }^{2,4}$ and Hernán Eduardo Echeverría ${ }^{1,3}$ \\ ${ }^{1}$ Estación Experimental Agropecuaria, INTA, C.C.276, Buenos Aires, 7620 Balcarce, Argentina \\ ${ }^{2}$ Consejo Nacional de Investigaciones Científicas y Técnicas (CONICET), Avenida Rivadavia 1917, \\ C1033AAJ Buenos Aires, Argentina \\ ${ }^{3}$ Facultad de Ciencias Agrarias, UNMDP, Unidad Integrada Balcarce, C.C.276, Buenos Aires, 7620 Balcarce, Argentina \\ ${ }^{4}$ Instituto de Investigaciones en Biodiversidad y Biotecnología, INBIOTEC-FIBA, Mar del Plata, Argentina
}

Correspondence should be addressed to Pablo Andrés Barbieri; barbieri.pablo@inta.gob.ar

Received 20 June 2014; Revised 14 August 2014; Accepted 2 September 2014; Published 23 September 2014

Academic Editor: Kent Burkey

Copyright (C) 2014 Pablo Andrés Barbieri et al. This is an open access article distributed under the Creative Commons Attribution License, which permits unrestricted use, distribution, and reproduction in any medium, provided the original work is properly cited.

No-till (NT) affects dynamics of phosphorus (P) applied. Wheat response to P fertilization can be affected by available soil P, grain yield, placement, rate, and timing of fertilization. Furthermore, mycorrhizal associations could contribute to improving plant $\mathrm{P}$ uptake. Three experiments were used to evaluate $\mathrm{P}$ rate $\left(0,25\right.$, and $\left.50 \mathrm{~kg} \mathrm{Pha}^{-1}\right)$ and fertilizer placement (broadcasted or deep-banded) effects in NT wheat on P recovery efficiency (PRE) yield and arbuscular mycorrhizal colonization (AMC) which was assessed in one experiment. Fertilization increased dry matter (DM) and accumulated P. Broadcasted P produced lower P accumulation than deep-banded P only at tillering. Phosphorus rate decreased PRE, and placement method did not affect it. Grain yield response was increased by $\mathrm{P}$ rate $\left(857\right.$ and $1805 \mathrm{~kg} \mathrm{ha}^{-1}$ for 25 and $50 \mathrm{~kg} \mathrm{Pha}^{-1}$, resp.) and was not affected by placement method (4774 and $5333 \mathrm{~kg} \mathrm{ha}^{-1}$ for broadcasted and deep-banded, resp.). Deep-banded P depressed root AMC compared with broadcast applications. Highest AMC in P broadcasted treatments could help to explain the lack of differences between placement methods. These results indicate that Mollisol have low P retention capacity. Therefore, broadcasted $\mathrm{P}$ could be used as an alternative of fertilizer management for NT wheat.

\section{Introduction}

Most agricultural production in Argentina comes from the Mollisols of the Pampas region; many of these are among the most fertile soils in the world [1]. These soils were developed under grassland from loess predominantly deposited by aeolian processes [2]. In this region Udic and thermic are the prevailing water and temperature regimes [1]. In general, the phosphorus (P) sorption capacity of these soils is relatively low $[3,4]$.

In this region, among winter crops, spring wheat is the most important. Within the Argentine Pampas Region, the Southeastern Buenos Aires province (Figure 1) represents an important wheat production area, contributing $20 \%$ to the national production. This area has an average annual temperature of $13.8^{\circ} \mathrm{C}$ and an average rainfall of $870 \mathrm{~mm}$, $45 \%$ of which occurs during the wheat growing season (June-December). It was reported that approximately in 3 out of $30 \mathrm{yr}$ the rainfall during the early season on a wheat crop (June-September) is lower than the potential evapotranspiration [5].

No-tillage agriculture (NT) has become more widespread in Argentina reaching approximately $67 \%$ of the total sowing area in the 2007-2008 growing season [6]. No-tillage produces physical, chemical, and biological changes in the soil, affecting both the dynamics and response of wheat to 


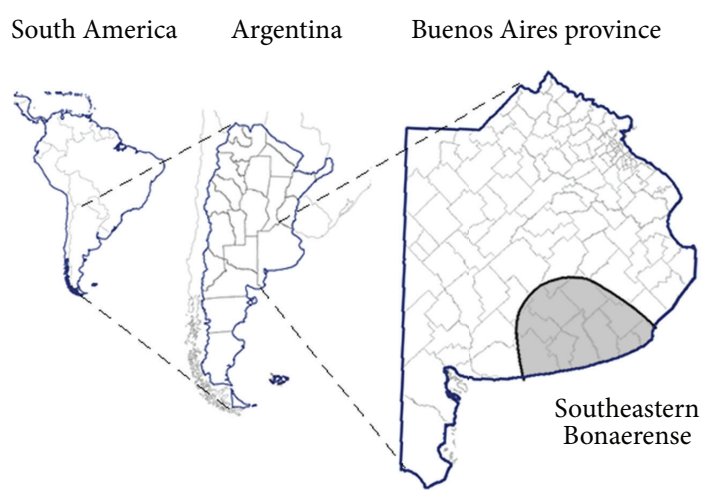

FIgUre 1: Map of South America indicating Argentina and the shadow area that comprises the Southeastern Buenos Aires.

$\mathrm{P}$ fertilization. It was reported that NT increases available $\mathrm{P}$, organic matter (OM) in soil surface horizons [7-9], and soil phosphatase activity [10] and produces changes in roots distribution, leading to greater root density in soil surface horizons [11]. High residue coverage usually increases soil moisture and reduces soil temperature at shallow depths, which can inhibit plant growth and $\mathrm{P}$ availability early in the season [12-14]. Guertal et al. [15] reported a low P retention capacity in surface soil under NT. This is likely a consequence of a high concentration of labile $\mathrm{P}$ forms (phosphate ions adsorbed with low retention energy), which saturates the $\mathrm{P}$ fixation sites, and of the greater OM concentration $[8,16]$ which would contribute to diminish $\mathrm{P}$ retention, due to a negative relationship between $\mathrm{OM}$ and $\mathrm{P}$ retention [17].

Soil environment, as well as the plant physiological conditions, can be greatly changed through tillage; therefore soil microbial populations could be also affected. It is well accepted that tillage directly affects all types of arbuscular mycorrhizal fungi (AMF) propagules (spores, colonized root fragments, and free hyphae of bulk soil) through different mechanisms acting together: (i) disruption of the hyphal network; (ii) dilution of the propagule-rich topsoil; and (iii) accelerated root decomposition [18]. Some reports have shown that tillage can reduce either AMF spore density [19] or root mycorrhizal colonization of crops and the potential for P uptake [20]. Damage to the hyphal network by tillage can reduce AMF growth and root colonization due to death or reduced infectivity of the hyphal fragments compared with intact networks and by detaching them from the host plants $[21,22]$. Kabir et al. [19, 23] have shown that disruption of hyphae through soil disturbance reduces infectivity and viability of AMF and thus depresses mycorrhizal potential. They showed that fallow had negative effects on the abundance of metabolically active hyphae were concurrent with the decrease in nutrient content by the corn plant. However the time between the disturbance and the viability of the hyphae is an aspect that should be considered. Kabir et al. [19] pointed that when most of the fallow periods (except $30 \mathrm{~d}$ of fallow) were applied, disturbance of the soil did not always reduce root mycorrhizal colonization. However, because mycorrhizal communities are site specific and each AMF species can be affected in several ways by different agricultural management practices, generalization is difficult.
For example, Menéndez et al. [24] found that tillage reduced spore number and AMF species diversity in agricultural soil of the Pampas region, whereas Schalamuk et al. [25] reported that tillage did not affect biodiversity of a soil from a wheat monoculture in the same region. While there are conflicting reports regarding the tillage and AMF, there are very few reports in relation to the location of $\mathrm{P}$ and mycorrhizae.

Land use and yield average of main crops were remarkably increased in the last 20 years in the Pampas Region [26]. This situation has generated a progressive decrease of nutrient such as $\mathrm{P}$, and, therefore, a generalized crop response to $\mathrm{P}$ application. In the Southeastern Buenos Aires province it has been reported that values of Bray-P [27] lower than $16 \mathrm{mg} \mathrm{kg}^{-1}$ soil decreased wheat grain yield [28]. In this area, greater $\mathrm{P}$ use efficiency was determined for banded ( $5 \mathrm{~cm}$ beside and below the seeds) compared to broadcasted fertilization at sowing under conventional tillage, mainly in soils with low available P levels (7 to $12 \mathrm{mg} \mathrm{kg}^{-1}$ ) [29, 30]. However, under NT, Bordoli and Mallarino [31] found no differences in maize grain yield between broadcasted before sowing ( 3 month) versus deep-banded (5-10 $\mathrm{cm}$ below surface) P fertilization. Similar results were reported by Bordoli et al. [32] for wheat under NT in a clay texture soil and low levels of available P (approximately $8 \mathrm{mg} \mathrm{kg}^{-1}$ ). Response of crops to P placement may also be affected by the amount and distribution of rainfall. In subhumid or semiarid regions with higher probability of rain deficit, $\mathrm{P}$ uptake from broadcasted $P$ fertilization could be restricted as consequence of low water content in the topsoil. This also produces changes in the growth, activity, and distribution of root with depth [33].

For high productivity crops in these conditions, formation of depletion zone (root-soil interface) of nutrients (mainly P) around the roots could be limiting for crop production. Although fertilization is the common used practice to minimize nutrient depletion, it is possible that contribution of AMF could contribute to P uptake beyond the rhizosphere depletion zone [34-36]. However, fertilization may negatively affect the formation of the symbiosis. Covacevich et al. [37] showed that the AMC of wheat roots was modulated (depressed by high $\mathrm{P}$ concentration) by current local soil available $\mathrm{P}$ as a result of fertilization with inorganic $\mathrm{P}$ source (superphosphate (SP)) but not by plant P status. Moreover, Covacevich et al. [30] found that fertilizer placement also affects indigenous AMC of wheat crops because deep-banded SP depresses indigenous mycorrhizal formation compared with broadcasted applications under tillage. However, the knowledge about the effect of $\mathrm{P}$ placement on wheat mycorrhiza under NT is still poor.

In the Southeastern Buenos Aires province little information exists about wheat response to broadcasted $\mathrm{P}$ under NT. Phosphorous fertilization broadcasted before sowing (3 months) is a practice that saves time and work at sowing, diminishes soil compaction, and eliminates operative disadvantages, mainly under wet climate conditions, that normally occur during wheat sowing period. Another advantage for broadcasted $\mathrm{P}$ is the decrease of the horizontal $\mathrm{P}$ variability caused by banded fertilization, which often increases the 
testing error of soil P availability [38]. Nevertheless, there are environmental risks associated with leaving $\mathrm{P}$ on the soil surface, P may be lost from soil through leaching and surface runoff. Especially in soils with low P-retention properties and/or significant preferential flow pathways (e.g., cracking clay soils) [39].

Efficient fertilizer management should combine rate, timing, placement, and source in a way that optimizes crop yield and quality, minimizing nutrient losses to the environment [40]. Because P fertilization is an important cost of crop production, there is a need to develop agricultural systems based on efficiently meeting crop requirements without applying excess fertilizer. This will require a detailed understanding of the processes governing soil $\mathrm{P}$ cycling and availability in which mycorrhizal symbiosis may play a significant role. Our hypothesis was that, in Mollisols under NT in the Southeastern Buenos Aires province, fertilizer P placement does not affect wheat grain yield, $\mathrm{P}$ uptake, and recovery efficiency of wheat crop. Our research objective was to evaluate the effects of $\mathrm{P}$ rate and placement in wheat crop under NT on P uptake, grain yield, and PRE. In addition, we evaluate arbuscular mycorrhizal colonization at a site to know whether the mycorrhizal symbiosis could help to explain some results obtained.

\section{Materials and Methods}

The study was conducted at three experimental sites: Tandil, Necochea, and Balcarce (Figure 1). Soils at Tandil and Mar del Plata are Typical Argiudolls, with loam texture in the surface layer (0 to $25 \mathrm{~cm}$ ), a loam to clay-loam texture in subsurface layers $(25$ to $110 \mathrm{~cm})$, and a sandy-loam texture below $110 \mathrm{~cm}$ depth (C horizon). The soil in Balcarce was a Petrocalcic Paleudoll, which presents discontinuous layers of Petrocalcic horizon below $0.8 \mathrm{~m}$ and greater clay contents at subsurface layers than Typical Argiudolls. These sites had 1\% slope and therefore no erosion is present, NT was initiated more than $7 \mathrm{yr}$ previously, and the entire crop rotation is corn, soybean, and double crop wheat/soybean. Some characteristics of management practices, cultivars, and the properties of the surface soil of the experimental sites are presented in Table 1.

At Tandil and Necochea the experimental design was randomized complete blocks with a factorial $(2 \times 2)$ treatment arrangement of $\mathrm{P}$ rate $\left(25\right.$ and $\left.50 \mathrm{~kg} \mathrm{Pha}^{-1}\right)$ and placement method ( $\mathrm{P}$ broadcasted 3 months before sowing) and $\mathrm{P}$ banded ( $5 \mathrm{~cm}$ beside and below the seeds sowing). Two reference treatments ( 0 and $150 \mathrm{~kg} \mathrm{Pha}^{-1}$ broadcasted) were also added for analysis of $\mathrm{P}$ response, and data were analysed using design randomized complete block ( $\mathrm{P}$ rate of 25 and $50 \mathrm{~kg} \mathrm{Pha}^{-1}$ were an average of banded and broadcast $\mathrm{P}$ application). Phosphorous response was evaluated using 0 , 25,50 , and $150 \mathrm{~kg} \mathrm{Pha}^{-1}$. In Balcarce, the experimental design was a randomized complete block, and treatments were 0 and $25 \mathrm{~kg}$ of $\mathrm{P} \mathrm{ha}^{-1}$ broadcasted or deep-banded. In all sites, the experimental units were $75 \mathrm{~m}^{-2}(5 \mathrm{~m} \times 15 \mathrm{~m})$. The P source was diammonium phosphate (18-46-0). Sulphur and N fertilizers were applied according to local recommendations at the rate of $10 \mathrm{~kg} / \mathrm{ha} \mathrm{S}$ (as calcium sulfate) and $150 \mathrm{~kg} \mathrm{~N} / \mathrm{ha}$ (as urea). The urea was applied at tillering [41], while S was applied at showing. Weeds were controlled with applications of metsulfuron methyl (methyl 2-[[[[(4-methoxy-6-methyl1,3,5-triazin-2-yl)amine]carbonil]amine]sulfonil] benzoate) at $6 \mathrm{~g}$ a.i. $\mathrm{ha}^{-1}$ plus 2,4-D (2,4-dicholorophenoxyacetic acid) at $0.5 \mathrm{~kg}$ a.i. ha ${ }^{-1}$. When necessary, insects were controlled by application of deltamethrin [(S)-Cyano-(3-phenoxyphenyl)methyl] (1R,3R)-3-(2,2-dibromoethenyl)-2,2-dimethyl-cyclopropane-1-carboxylate at $5 \mathrm{~g}$ a.i. $\mathrm{ha}^{-1}$.

At Tandil and Necochea $0-10$ and $10-20 \mathrm{~cm}$ soil samples were collected at tillering $[42](Z=22)$ and flowering $(Z=60)$ and Bray-P was determined. Only at Necochea at $Z=22$ and $Z=60,4$ soil samples per plot ( 2 in the row and 2 inter-row) were collected for AMC determination (10 cores of $5 \mathrm{~cm}$ diameter and $20 \mathrm{~cm}$ depth). Each soil core was divided in 2 subfractions of $0-10$ and $10-20 \mathrm{~cm}$; roots of each soil depth were separated from soil, washed to remove soil particles, collected on a sieve $(2 \mathrm{~mm})$ cut thoroughly, mixed, and stained according to the Phillips and Hayman [43] modified method. Briefly roots were cleared with $\mathrm{KOH}\left(10 \%, 30 \mathrm{~min}, 100^{\circ} \mathrm{C}\right)$, acidified with $\mathrm{HCl}(0.1 \mathrm{~N}$, $2 \mathrm{~min})$, and stained with Trypan Blue $\left(0.05 \%, 5 \mathrm{~min}, 100^{\circ} \mathrm{C}\right)$ in lactoglycerol (lactic acid, glycerol, distilled water $1: 1: 1$ ). The occurrence of mycorrhizal colonization was assessed by microscopic examination (40x and 100x) of the stained roots system. A segment was considered colonized if it contained arbuscules, coils plus hyphae, and/or vesicles. Colonization was assessed using the Trouvelot et al. [44] method that allowed the simultaneous evaluation of the intensity of AMC and the proportion of arbuscules of roots.

Soil P retention capacity [45] was determined in $0-10$ and $10-20 \mathrm{~cm}$ soil samples from the Necochea site that were collected at sowing from the control treatment $(0 \mathrm{P})$. Inorganic $\mathrm{P}$ in the supernatant was determined by colorimetry [46]. $P$ retention was analyzed using a split-plot in a randomized complete blocks design with three replications, where the main plot was the soil depth $(0-10$ and $10-20 \mathrm{~cm})$ and the subplot was the three concentrations of $\mathrm{P}$ added $(0,60$, and $120 \mathrm{ug} P$ per $g$ soil). Percentage of $\mathrm{P}$ retention was calculated as $100-(($ Bray P60 or $120-$ Bray P0)/60 or120) * 100 using Bray-P [27], and percentage of $P$ recovery was calculated as ((Bray P60 or $120-$ Bray P0)/60 or 120$) * 100$.

For all sites, aboveground DM accumulation at tillering, first node, flowering, and physiological maturity were determined by harvesting an area of $1.2 \mathrm{~m}^{2}$. At maturity, the harvest was done by cropper and grain yield was determined by harvesting an area of $9.6 \mathrm{~m}^{2}$ and expressed to $140 \mathrm{~g} \mathrm{~kg}^{-1}$ grain moisture content. At Tandil and Necochea, plant $\mathrm{P}$ accumulation [47] was measured at tillering $(Z=22)$, first node $(Z=31)$, flowering $(Z=60)$, and physiological maturity. Grain $P$ and straw content were determined separately. At physiological maturity, PRE in DM (grain + straw) and grain were calculated as follows: ( $\mathrm{P}$ content in $\mathrm{DM}$ or grain at the fertilized treatments - P content in DM or grain at control $(0 \mathrm{P})) / \mathrm{P}$ rate.

Treatment effects were evaluated by analysis of variance using the SAS software [48]. Interactions among sources of variations (for all sites, harvest and evaluated parameters) 
TABLE 1: Some characteristics of the soil surface at Tandil, Necochea, and Balcarce experimental sites.

\begin{tabular}{|c|c|c|c|c|c|c|c|c|c|c|c|}
\hline Site & $\begin{array}{c}\text { OM } \\
\%\end{array}$ & $\begin{array}{c}\mathrm{AP} \\
\mathrm{mg} \mathrm{kg}^{-1}\end{array}$ & $\mathrm{pH}$ & Texture & $\mathrm{PC}$ & Tillage & Cultivar & $\begin{array}{l}\text { Row spacing } \\
(\mathrm{cm})\end{array}$ & Seeding date & $\begin{array}{c}\text { Seeding rate } \\
\mathrm{kg} \mathrm{ha}^{-1}\end{array}$ & Harvest date \\
\hline Tandil & 5.5 & 8.9 & 6.3 & Loam & $\mathrm{Sb}$ & No-till & Prointa Isla Verde & 19.0 & August 15 & 140 & December 27 \\
\hline Necochea & 5.7 & 13.9 & 6.0 & Loam & $\mathrm{Sb}$ & No-till & Klein Dragon & 19.0 & August 12 & 140 & December 28 \\
\hline Balcarce & 4.3 & 9.9 & 6.2 & Loam & $\mathrm{Sb}$ & No-till & Baguette 19 & 17.5 & July 18 & 120 & December 23 \\
\hline
\end{tabular}

OM: organic matter [66]; AP: available phosphorus (Bray and Kurtz 1945) [27]; PC: previous crop; Sb: soybean.

TABLE 2: Monthly rainfall $(\mathrm{mm})$, mean minimum temperature $\left({ }^{\circ} \mathrm{C}\right)$, mean maximum temperature $\left({ }^{\circ} \mathrm{C}\right)$, and crop evapotranspiration $(\mathrm{CET})$ during wheat growing season at Tandil, Necochea, and Balcarce experimental sites.

\begin{tabular}{|c|c|c|c|c|c|c|c|c|c|c|c|c|}
\hline & \multicolumn{4}{|c|}{ Tandil } & \multicolumn{4}{|c|}{ Necochea } & \multicolumn{4}{|c|}{ Balcarce } \\
\hline & $\begin{array}{r}\text { Rainfall } \\
\mathrm{mm}\end{array}$ & CET & Temp. Min & $\begin{array}{l}\text { Temp. Max } \\
\text { C }\end{array}$ & $\begin{array}{r}\text { Rainfall } \\
\mathrm{mr}\end{array}$ & CET & Temp. Min & $\begin{array}{l}\text { Temp. Max } \\
\text { C }\end{array}$ & $\begin{array}{r}\text { Rainfall } \\
\mathrm{mn}\end{array}$ & CET & Temp. Min & $\begin{array}{l}\text { Temp. Max } \\
\text { C }\end{array}$ \\
\hline July & 41 & 22 & 3.1 & 12.3 & 131 & 27.1 & 2.6 & 12.3 & 13 & 29 & 0.7 & 11.3 \\
\hline August & 132 & 36 & 5.9 & 14.0 & 55 & 37.9 & 3.1 & 13.3 & 25 & 41 & 1.4 & 12.1 \\
\hline September & 58 & 35 & 5.0 & 15.3 & 17 & 50.4 & 4.9 & 16.2 & 183 & 58 & 7.6 & 17.2 \\
\hline October & 175 & 72 & 9.1 & 20.5 & 100 & 91.5 & 7.8 & 20.0 & 117 & 92 & 9.9 & 20.1 \\
\hline November & 143 & 76 & 11.4 & 22.1 & 76 & 111.5 & 9.2 & 21.8 & 45 & 113 & 7.4 & 21.9 \\
\hline December & 56 & 84 & 13.4 & 25.5 & 118 & 136.8 & 11.9 & 24.0 & 35 & 161 & 11.8 & 27.3 \\
\hline
\end{tabular}

were not significant. Thus plant and soil data are shown as affected by pure treatments. The AMC data were analysed as independent treatment at each soil depth. Differences in means for DM, $\mathrm{P}$ uptake, PRE, grain yield, $\mathrm{P}$ retention in soil, and AMC were compared with the Duncan multiple range test $(P<0.05)$. All presented data are means of untransformed values.

\section{Results and Discussion}

3.1. Environmental Characterization of Experiments. Some characteristics of rainfall, crop evapotranspiration [49], and temperatures (minimum and maximum) during the wheat growing season are present in Table 2. Accumulated rainfall during June-December was 617 and $506 \mathrm{~mm}$ in Tandil and Necochea, respectively. Water balances for the wheat crops during growing seasons were calculated taking into account soil water storage capacity [50] (Figure 2). Water availability did not limit wheat growth or grain yields in these sites, and in consequence high grain yield were achieved (4970 and $6160 \mathrm{~kg} \mathrm{ha}^{-1}$ on average of $\mathrm{P}$ rate at Tandil and Necochea, resp.). At Balcarce, accumulated rainfall during June-December was $447 \mathrm{~mm}$ and water stress occurred after flowering (later November-December) which may have affected grain-filling and in consequence grain yield. Additionally, low temperatures in November caused frost damage, affecting wheat grain yield $\left(3790 \mathrm{~kg} \mathrm{ha}^{-1}\right.$ averaged over $\mathrm{P}$ rates).

3.2. Aboveground Dry Matter Accumulation. Phosphorus rate and placement affected DM accumulation (Table 3). For all sites, $\mathrm{P}$ fertilization increased DM accumulation indicating that soil $\mathrm{P}$ availability affected wheat growth (Table 3). Available soil $\mathrm{P}$ at sowing was $8.9,13.9$, and $9.9 \mathrm{mg} \mathrm{kg}^{-1}$ in
Tandil, Necochea, and Balcarce, respectively, and these values were lower than the $\mathrm{P}$ response threshold of $16-17 \mathrm{mg} \mathrm{kg}^{-1}$ [28]. Phosphorus rate of $150 \mathrm{~kg} \mathrm{ha}^{-1}$ produced a greater DM accumulation than 25 and $50 \mathrm{~kg} \mathrm{Pha}^{-1}$ only in Necochea at tillering and at first node (Table 3). Placement method affected wheat crop growth mainly during early stages. At Balcarce, the same tendency was observed, although the difference between placement methods was not statistically significant (Table 3). Dry matter accumulation was not affected by fertilizer placement at flowering and physiological maturity (Table 3 ). These results indicate that initial soil $\mathrm{P}$ availability in the banded treatment was greater than in the broadcasted treatment. This agrees with data reported by Mallarino et al. [51] and Borges and Mallarino [14] for maize and soybean in Iowa, respectively. These authors determined higher DM accumulation and P uptake at initial growth stages for banded $\mathrm{P}$ applications than for broadcast application (3 or 4 months before sowing).

3.3. Phosphorus Accumulation in Aboveground Dry Matter and Phosphorus Recovery Efficiency. At Tandil and Necochea, DM $\mathrm{P}$ accumulation was increased by $\mathrm{P}$ rate, and, for all stages, plots fertilized with $150 \mathrm{~kg} \mathrm{Pha}^{-1}$ produced greater $\mathrm{P}$ accumulation than the 25 and $50 \mathrm{~kg} \mathrm{Pha}^{-1}$ treatments (Table 4). Nevertheless, placement method affected accumulated $\mathrm{P}$ only at tillering (Table 4). It is probable that low soil temperatures typically observed at initial stages of the growing season, which are likely lower under NT [52], could have diminished $\mathrm{P}$ diffusion to roots, root growth, and $\mathrm{P}$ uptake from broadcast P [52]. For both sites, P content in grain increased with $\mathrm{P}$ rate but was not affected by placement method (Table 3 ). Harvest $\mathrm{P}$ index was not affected by $\mathrm{P}$ rate or fertilization placement method, and it was on average $73 \%$; this value is similar to that reported by García and Berardo [28]. 


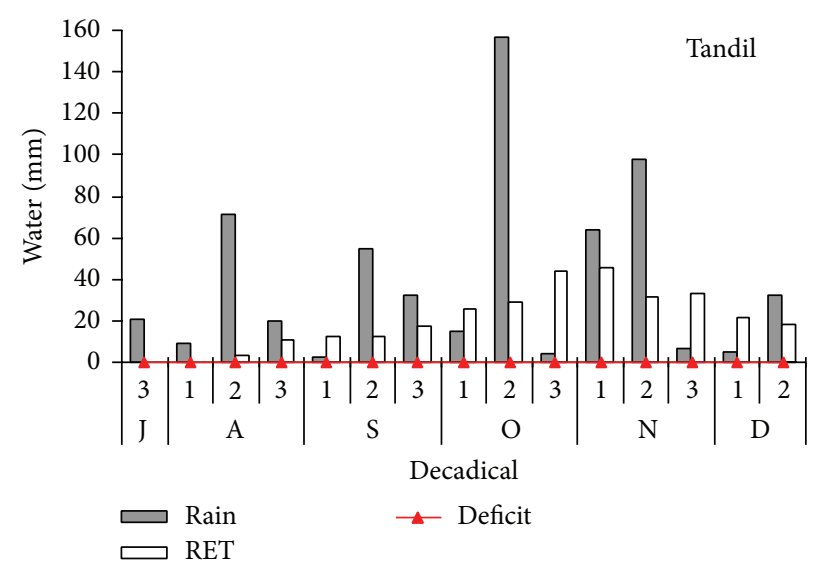

(a)

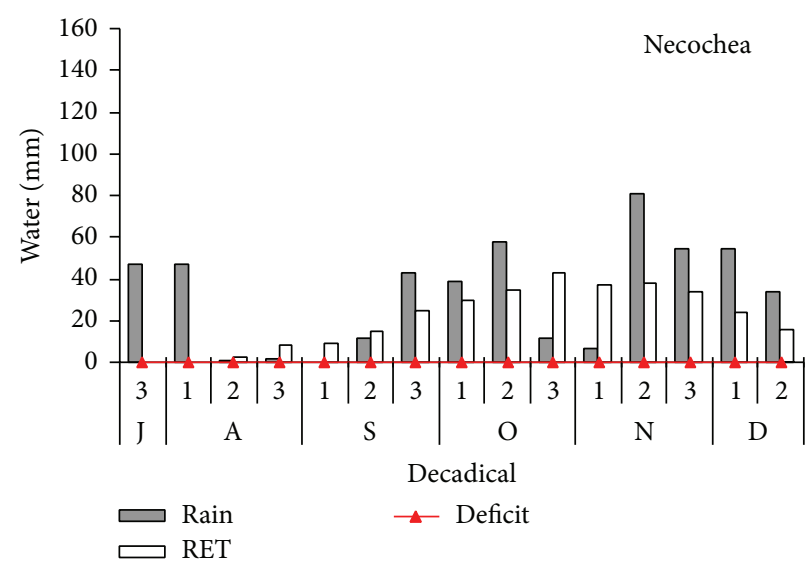

(b)

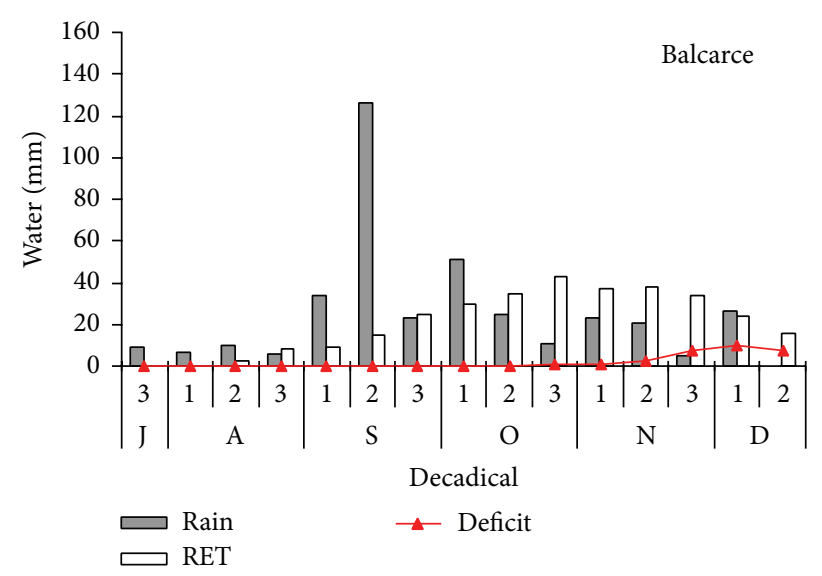

(c)

FIGURE 2: Precipitation, real evapotranspiration (RET), and water deficit during wheat growing season at Tandil, Necochea, and Balcarce sites.

Plant $P$ recovery (grain plus residues) efficiency at physiological maturity decreased with $\mathrm{P}$ rate and was not affected by fertilization placement method (Figure 3). A similar observation was obtained for PRE in grain (Figure 3 ) with higher values than those reported by Halvorson and Havlin [53], which oscillated from 4 to $5.4 \%$ for rates 34 and $68 \mathrm{~kg} \mathrm{Pha}^{-1}$, in winter wheat under NT grown in calcareous soils with $\mathrm{pH}$ 7.8. These differences indicate that soils (Typical Argiudolls) of Southeastern Buenos Aires province with subacid pH may have a low $\mathrm{P}$ retention capacity. These results are similar to those reported by Berardo et al. [54].

3.4. Grain Yield. Tandil and Necochea had higher grain yields than Balcarce (Figure 4) likely due to more favourable climatic conditions. At all sites grain yield was increased by $\mathrm{P}$ rate and was not affected by fertilization placement method (Figure 4). At Tandil site only the $25 \mathrm{~kg} \mathrm{Pha}^{-1}$ rate did not increase grain yield compared to control $(P=0.06)$ while in Necochea site the maximum grain yield was reached with $25 \mathrm{~kg} \mathrm{Pha}^{-1}$. Grain weight was not affected by $\mathrm{P}$ rate (data not shown) indicating that $\mathrm{P}$ availability affected the grain number, which agrees with that reported by other authors [55, 56]. Low $\mathrm{P}$ availability affects wheat growth by reducing the rate of emergence and leaf expansion, the number of tillers, and the rate of photosynthesis per unit leaf area $[57,58]$, resulting in reduced interception and conversion efficiency of incident radiation. Lázaro and Abbate [56] reported that $\mathrm{P}$ stress reduces the grain number by a lower production of photoassimilates during spike growth period. Similar grain yield for broadcast and banded P suggests that reduced crop growth rates, caused by early $\mathrm{P}$ deficiency, did not affect the crop growth rate during the critical period for kernel set.

The similar yield for broadcasted $\mathrm{P}$ application compared to deep-banded $\mathrm{P}$ agrees with that reported by Bordoli and Mallarino [31] and Borges and Mallarino [14], for corn and soybean under NT, respectively. However, these results did not agree with those reported for wheat under CT by Berardo et al. [29] and Covacevich et al. [30], who found differences between banded and broadcast $\mathrm{P}$ applications when soil P-Bray was less than $12-13 \mathrm{mg} \mathrm{kg}^{-1}$. This suggests that the tillage system could affect the crop response to the P placement method. Halvorson and Havlin [53] for winter wheat under NT reported greater grain yield for banded $\mathrm{P}$ application than broadcast mainly at low $\mathrm{P}$ rate in soils with $\mathrm{pH}$ of 7.8. However, our results suggest similar grain yield response between placement regardless of the $\mathrm{P}$ rate and initial available soil Bray-P content. 
TABLE 3: Aerial dry matter accumulation affected by P rate and placement method at Tandil, Necochea, and Balcarce experimental sites.

\begin{tabular}{|c|c|c|c|c|}
\hline & Tillering & First node & Flowering & $\mathrm{PM}$ \\
\hline \multicolumn{5}{|c|}{ Tandil } \\
\hline $\mathrm{P}$ response & & & $\mathrm{kgha}^{-1}$ & \\
\hline 0 & $218 \mathrm{a}$ & $1262 \mathrm{~b}$ & $6175 \mathrm{a}$ & 10958 a \\
\hline 25 & $303 \mathrm{a}$ & $1961 \mathrm{a}$ & $6668 \mathrm{a}$ & $13438 \mathrm{a}$ \\
\hline 50 & $320 \mathrm{a}$ & $2137 \mathrm{a}$ & $7669 \mathrm{a}$ & $13346 \mathrm{a}$ \\
\hline 150 & $349 \mathrm{a}$ & $2432 \mathrm{a}$ & $7802 \mathrm{a}$ & $14111 \mathrm{a}$ \\
\hline Broadcast $(B)$ & $282 \mathrm{~b}$ & $1808 \mathrm{a}$ & $7136 \mathrm{a}$ & $13739 \mathrm{a}$ \\
\hline Deep-banded $(L)$ & $341 \mathrm{a}$ & $2200 \mathrm{a}$ & $7201 \mathrm{a}$ & $13046 \mathrm{a}$ \\
\hline$B \times L$ & ns & ns & ns & $\mathrm{ns}$ \\
\hline \multicolumn{5}{|c|}{ Necochea } \\
\hline $\mathrm{P}$ response & & & $\mathrm{kgha}^{-1}$ & \\
\hline 0 & $288 \mathrm{~d}$ & $2939 c$ & $8795 \mathrm{~b}$ & $15306 \mathrm{a}$ \\
\hline 25 & $495 \mathrm{c}$ & $4519 \mathrm{~b}$ & 10377 a & $16229 \mathrm{ab}$ \\
\hline 50 & $587 \mathrm{~b}$ & $4706 \mathrm{~b}$ & $11254 \mathrm{a}$ & $16917 \mathrm{ab}$ \\
\hline 150 & $693 a$ & $5028 \mathrm{a}$ & $10602 \mathrm{a}$ & $17247 \mathrm{~b}$ \\
\hline Broadcast $(B)$ & $458 \mathrm{~b}$ & $4402 \mathrm{~b}$ & $10501 \mathrm{a}$ & $16549 \mathrm{a}$ \\
\hline Banded $(L)$ & $624 \mathrm{a}$ & $4824 \mathrm{a}$ & 11129 a & $16597 \mathrm{a}$ \\
\hline$B \times L$ & ns & $\mathrm{ns}$ & $\mathrm{ns}$ & $\mathrm{ns}$ \\
\hline \multicolumn{5}{|c|}{ Balcarce } \\
\hline P response & & & $\mathrm{kgha}^{-1}$ & \\
\hline $0-\mathrm{P}$ & $478 \mathrm{~b}$ & $1557 \mathrm{~b}$ & $6838 \mathrm{a}$ & $9188 \mathrm{~b}$ \\
\hline 25-P-broadcast & $761 \mathrm{a}$ & 1987 a & $7724 \mathrm{a}$ & 11103 a \\
\hline 25-P-banded & $932 \mathrm{a}$ & $2171 \mathrm{a}$ & $7267 \mathrm{a}$ & $12146 \mathrm{a}$ \\
\hline
\end{tabular}

Means in the same column followed by the same letter are not significantly different from each other based on the Duncan test (0.05). Phosphorus response is compared using $0,25,50$, and $150 \mathrm{P}$ rates. Phosphorus placement method is only compared at 25 and $50 \mathrm{P}$ rates. PM: physiological maturity; ns: not significant.

TABle 4: Accumulated phosphorous in aerial dry matter. P content in grain and phosphorous harvest index (PHI) at Tandil and Necochea experimental sites.

\begin{tabular}{|c|c|c|c|c|c|c|}
\hline & Tillering & First node & Flowering & $\mathrm{PM}$ & P Grain & $\mathrm{PHI}$ \\
\hline \multicolumn{7}{|c|}{ Tandil } \\
\hline $\mathrm{P}$ response & & & $\mathrm{kg} \mathrm{Pha}^{-1}$ & & & $\%$ \\
\hline 0 & $0.42 \mathrm{~b}$ & $3.63 c$ & $16.70 \mathrm{~b}$ & $14.55 \mathrm{~b}$ & $12.74 \mathrm{c}$ & $0.87 \mathrm{a}$ \\
\hline 25 & $0.96 \mathrm{ab}$ & $7.05 \mathrm{bc}$ & $16.42 \mathrm{~b}$ & $19.06 \mathrm{~b}$ & $15.17 \mathrm{bc}$ & $0.80 \mathrm{a}$ \\
\hline 50 & $1.24 \mathrm{ab}$ & $8.52 \mathrm{~b}$ & $20.10 \mathrm{ab}$ & $20.13 \mathrm{ab}$ & $16.57 \mathrm{ab}$ & $0.82 \mathrm{a}$ \\
\hline 150 & $1.61 \mathrm{a}$ & $14.8 \mathrm{a}$ & $24.31 \mathrm{a}$ & $25.32 \mathrm{a}$ & $19.08 \mathrm{a}$ & $0.76 \mathrm{a}$ \\
\hline Broadcast $(B)$ & $0.88 \mathrm{a}$ & $7.74 \mathrm{a}$ & $18.92 \mathrm{a}$ & $19.93 \mathrm{a}$ & $16.00 \mathrm{a}$ & $0.81 \mathrm{a}$ \\
\hline Banded $(L)$ & $1.32 \mathrm{a}$ & $7.84 \mathrm{a}$ & $17.60 \mathrm{a}$ & $19.27 \mathrm{a}$ & $15.74 \mathrm{a}$ & $0.81 \mathrm{a}$ \\
\hline$B \times L$ & $\mathrm{~ns}$ & ns & ns & ns & ns & ns \\
\hline \multicolumn{7}{|c|}{ Necochea } \\
\hline P response & & & $\mathrm{kgPha}^{-1}$ & & & $\%$ \\
\hline 0 & $0.72 \mathrm{~d}$ & $6.66 c$ & $14.64 \mathrm{c}$ & $18.15 \mathrm{c}$ & $14.07 \mathrm{c}$ & $0.78 \mathrm{a}$ \\
\hline 25 & $1.83 \mathrm{c}$ & $10.18 \mathrm{cb}$ & $18.03 \mathrm{bc}$ & $22.34 \mathrm{bc}$ & $17.47 \mathrm{~b}$ & $0.78 \mathrm{a}$ \\
\hline 50 & $2.49 \mathrm{~b}$ & $12.78 \mathrm{~b}$ & $21.25 \mathrm{~b}$ & $26.71 \mathrm{~b}$ & $19.60 \mathrm{a}$ & $0.78 \mathrm{a}$ \\
\hline 150 & $3.12 \mathrm{a}$ & $16.88 \mathrm{a}$ & $26.39 \mathrm{a}$ & $34.73 \mathrm{a}$ & $20.70 \mathrm{ab}$ & $0.58 \mathrm{~b}$ \\
\hline Broadcast $(B)$ & $1.59 \mathrm{~b}$ & $12.04 \mathrm{a}$ & $19.72 \mathrm{a}$ & $24.57 \mathrm{a}$ & $18.93 \mathrm{a}$ & $0.77 \mathrm{a}$ \\
\hline Banded $(L)$ & $2.65 \mathrm{a}$ & $10.93 \mathrm{a}$ & $19.66 \mathrm{a}$ & $24.47 \mathrm{a}$ & $19.24 \mathrm{a}$ & $0.79 \mathrm{a}$ \\
\hline$B \times L$ & ns & ns & ns & ns & ns & ns \\
\hline
\end{tabular}

Means in the same column followed by the same letter are not significantly different from each other based on the Duncan test (0.05). Phosphorus response is compared using $0,25,50$, and $150 \mathrm{P}$ rates. Phosphorus placement method is only compared at 25 and $50 \mathrm{P}$ rates PM: physiological maturity; ns: not significant. 


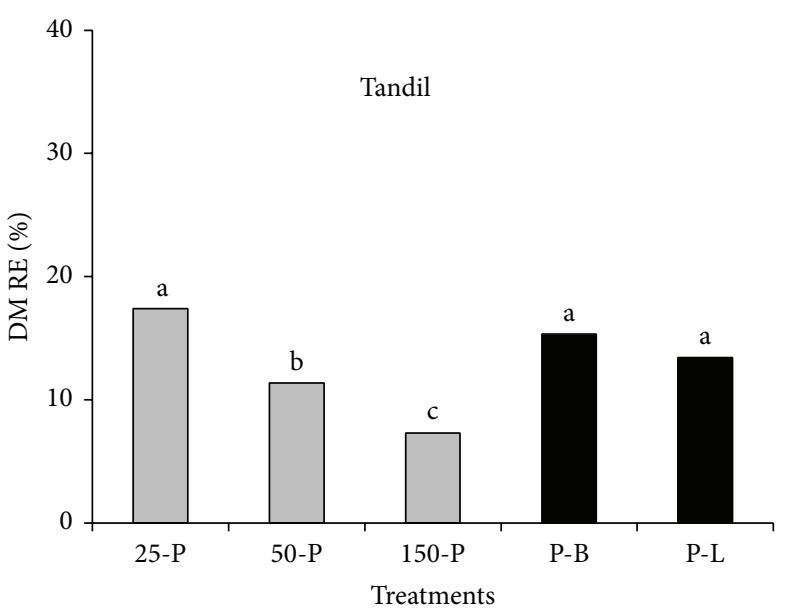

(a)

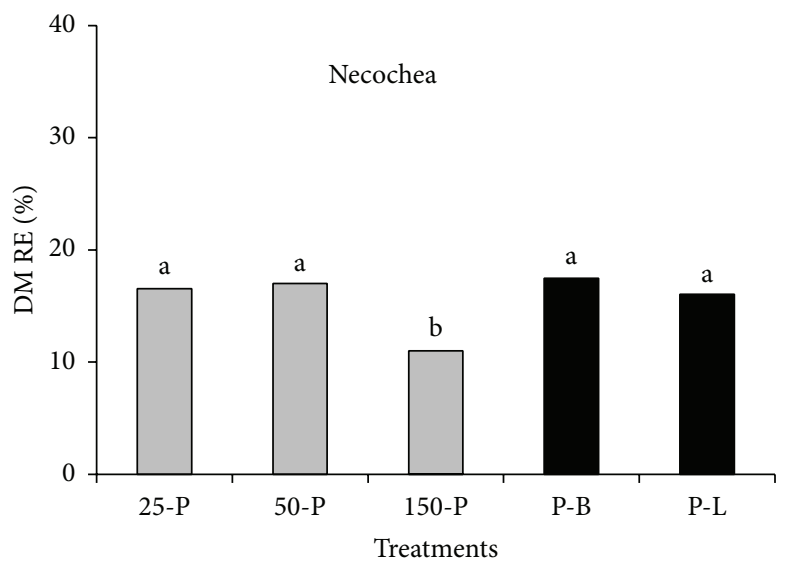

(c)

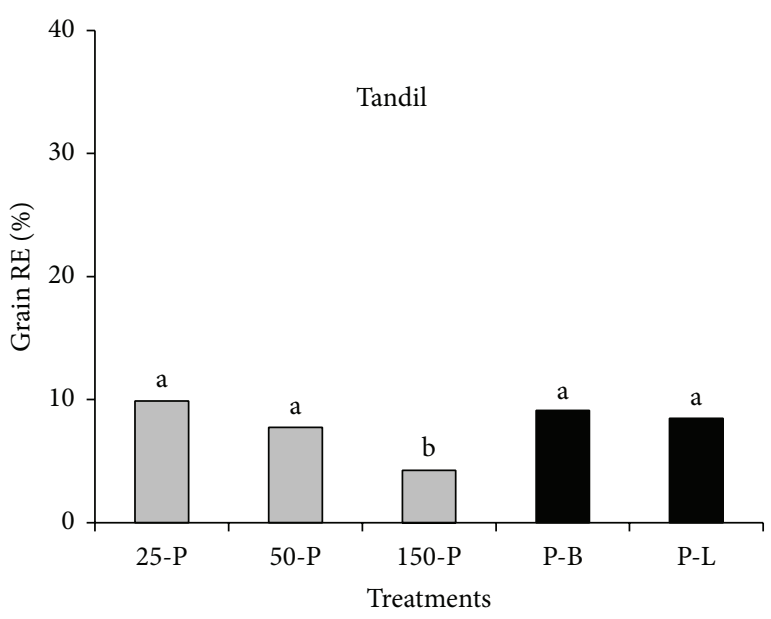

(b)

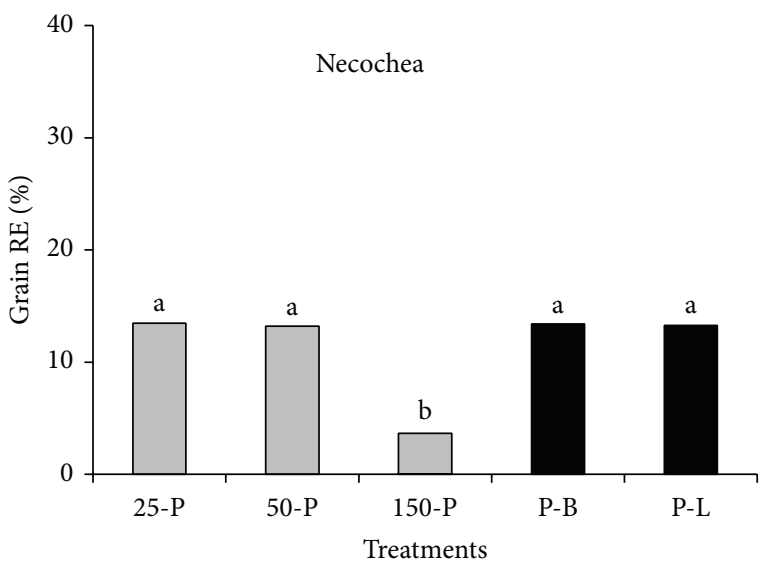

(d)

FIgURE 3: Phosphorus recovery efficiency (PRE) in dry matter (DM = grain + residues) and grain of NT wheat as affected by placement method and $\mathrm{P}$ rate. Means followed by the same letter are not significantly different from each other based on the Duncan test (0.05). Phosphorus response is compared using 25,50, and $150 \mathrm{P}$ rates (gray). Phosphorus placement method is only compared at 25 and $50 \mathrm{P}$ rates (black). P-B; phosphorus broadcasted. P-L: phosphorus banded at sowing.

3.5. Effect of Fertilization Placement Method on Bray-P Content and Phosphorus Recovery. No significant interaction between $\mathrm{P}$ rate and placement method was found for BrayP content at $0-10 \mathrm{~cm}$ and $10-20 \mathrm{~cm}$ soil depths. Phosphorous fertilization increased Bray-P concentration in the $0-10 \mathrm{~cm}$ and $10-20 \mathrm{~cm}$ soil depths. Highest soil P contents were found within the top $10 \mathrm{~cm}$ of the soil profile when compared to the 10-20 cm depth (Figure 5). Our results are also in accordance with the $\mathrm{P}$ decrease throughout the soil profile of soils from the Southeastern Buenos Aires province [59]. Moreover, Culleton and Murphy [60] have also shown that the slow $\mathrm{P}$ mobility through the soil normally does not surpass $10 \mathrm{~cm}$ of soil depth.

Fertilization placement method did not affect soil Bray$P$ concentration in $0-10 \mathrm{~cm}$ and $10-20 \mathrm{~cm}$ soil depths (Figure 5). The greater Bray-P concentration in the $10-20 \mathrm{~cm}$ soil depth in fertilized treatments compared to the control (0-P) would suggest that broadcast P moved up to $10-20 \mathrm{~cm}$ into the soil. Phosphorus retention was affected by $\mathrm{P}$ rate and sampling depth (Table 5). Phosphorus rate at $60(\mu \mathrm{g}$
$\mathrm{P}$ per $\mathrm{g}$ soil) shows a greater retention than 120 (Table 5), indicating that the $\mathrm{P}$ fixation by the soil is more important at low $\mathrm{P}$ rates of this nutrient. Lower retention of $\mathrm{P}$ added was observed in the $0-10 \mathrm{~cm}$ depth compared to the $10-20 \mathrm{~cm}$ soil depth (Table 5); similar results were reported for soils under long term NT by Guertal et al. [15]. These authors determined that $\mathrm{P}$ retention varied from 8 to $14 \%, 19$ to $32 \%$, and 34 to $57 \%$ of $P$ added, for $0-2 \mathrm{~cm}, 6-8 \mathrm{~cm}$, and $16-18 \mathrm{~cm}$ soil depths. Possible mechanisms that explain this behaviour are high saturation of $\mathrm{P}$ retention sites and the high $\mathrm{OM}$ content of surface soil [15]. The great increase of Bray-P in the first $0-10 \mathrm{~cm}$ and movement of $\mathrm{P}$ in the soil horizon would indicate low $\mathrm{P}$ retention of surface soil, allowing that fertilizer $\mathrm{P}$ remains in labile mineral forms or that remain as phosphate in solution [15]. Low $\mathrm{P}$ retention under nonlabile forms might be a consequence of acidic $\mathrm{pH}$, low clay content $(1: 1)$, low interchangeable $\mathrm{Al}$, low $\mathrm{Al}$ and $\mathrm{Fe}$ oxides of Molisolls of Southeastern Buenos Aires province and the changes originated by NT, like stratification of $\mathrm{P}$ and $\mathrm{OM}$ [61]. Therefore, changes in concentration of Bray-P in depth 


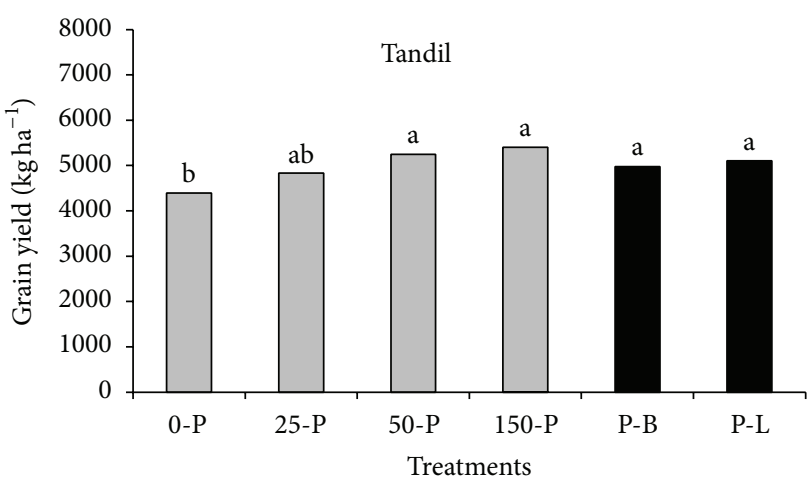

(a)

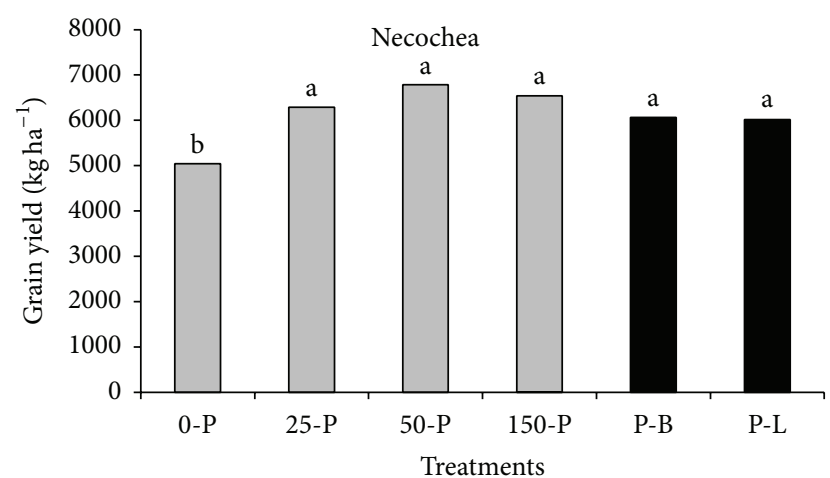

(b)

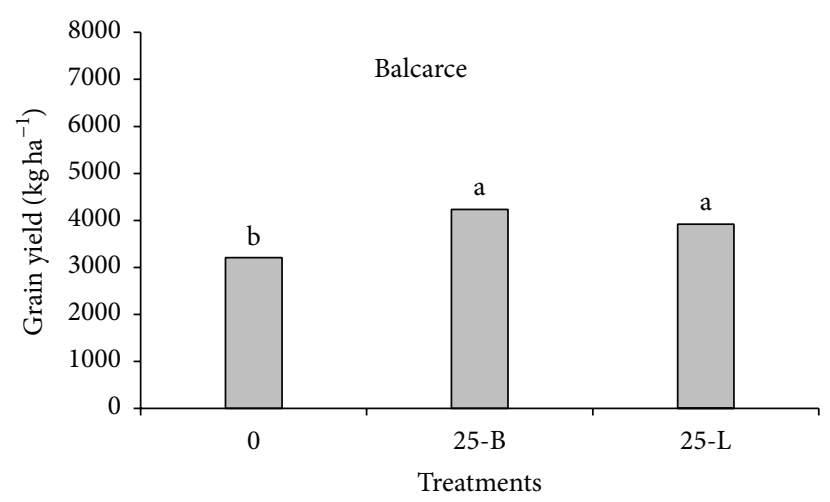

(c)

FIGURE 4: Spring wheat grain yield affected by P placement method and P rate. Means followed by the same letter are not significantly different from each other based on the Duncan test (0.05). Phosphorus response is compared using 0, 25, 50, and $150 \mathrm{P}$ rates (gray). Phosphorus placement method is only compared at 25 and $50 \mathrm{P}$ rates (Tandil and Necochea). P-B: phosphorus broadcasted. P-L: phosphorus banded at sowing.

determined in this experiment could be the consequence of low P retention capacity of the soil surface layer under NT and the precipitation fell between broadcast $\mathrm{P}$ and soil sampled that is in concordance with a period to soil profile recharge water. These processes could have contributed to increase P availability for the wheat crop after tillering. Low P-fixing capacity in soils of this area were informed by Picone et al. [62].

3.6. Arbuscular Mycorrhizal Colonization. Highest AMC of wheat roots was found in the unfertilized treatments both at tillering and at flowering stages (Figure 6). Fertilization with 25 and $50 \mathrm{~kg} \mathrm{Pha}{ }^{-1}$ deep-banded decreased AMC for both sampling times and depths. However, the increase in the $\mathrm{P}$ rate did not produce similar marked depressions in AMC when the $\mathrm{P}$ was broadcast. Although available soil $\mathrm{P}$ was higher in the upper soil layer than in the lower (Figure 5), there were no differences in colonization between soil depths. In the upper soil $0-10 \mathrm{~cm}$ we found greater AMC at tillering for broadcast $\mathrm{P}$ at 25,50 , and $150 \mathrm{~kg} \mathrm{P} \mathrm{ha}^{-1}$ than in deep-banded $\mathrm{P}$ at 25 or $50 \mathrm{~kg} \mathrm{P} \mathrm{ha}^{-1}$ (Figure 6). Although differences were reduced at flowering and sometimes were not significant, threefold higher AMC in 25 and $50 \mathrm{~kg} \mathrm{ha}^{-1}$ broadcasted treatments than in deep-banded ones were
TABLE 5: Analysis of variance of P recovery (\%) at Necochea affected by $\mathrm{P}$ rate and soil depth.

\begin{tabular}{lc}
\hline \multicolumn{2}{c}{ ANOVA } \\
\hline Source of variation & $P>F$ \\
P rate $(R)$ & 0.003 \\
Soil depth $(D)$ & 0.012 \\
$R \times D$ & $\mathrm{~ns}$ \\
\hline \multicolumn{2}{l}{ Average treatments } \\
\hline P rate $\left(\mu \mathrm{g} \mathrm{g} \mathrm{soil}^{-1}\right)$ & \% retention \\
60 & $33.2 \mathrm{a}$ \\
120 & $28.5 \mathrm{~b}$ \\
Soil depth $(\mathrm{cm})$ & \\
$0-10$ & $29.1 \mathrm{~b}$ \\
$10-20$ & $32.6 \mathrm{a}$ \\
\hline
\end{tabular}

Means in the same column followed by the same letter are not significantly different from each other based on the Duncan test (0.05). ns: not significant.

found. Because arbuscules had a similar behaviour to AMC with regard to fertilization treatments and soil depth (data are shown), we believe that fertilization and P placement affected arbuscules in the same way. 


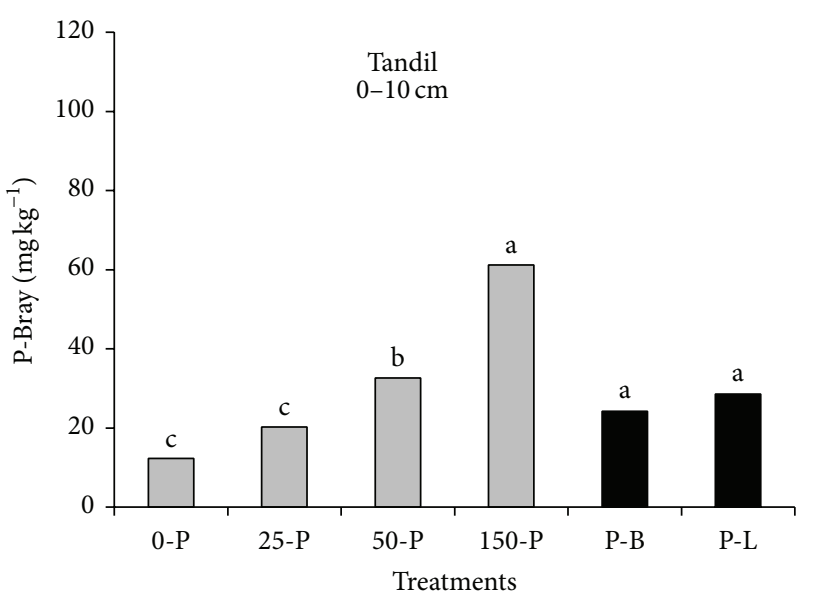

(a)

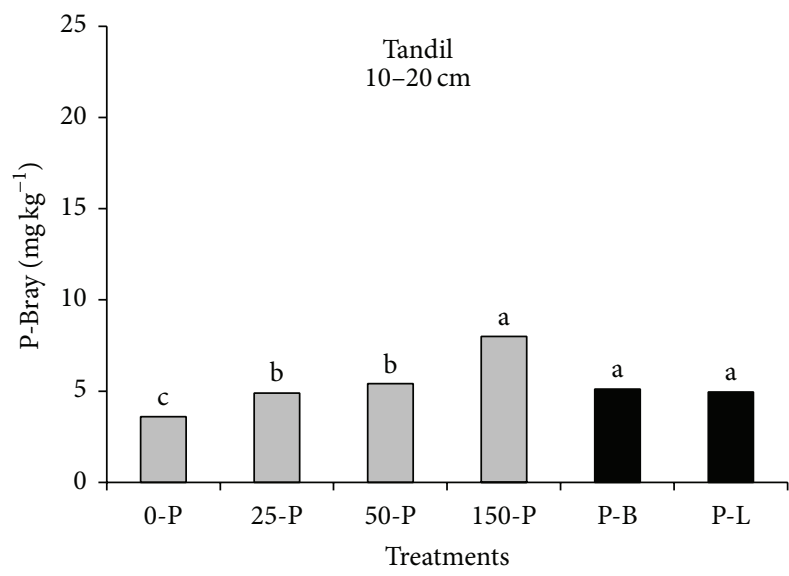

(c)

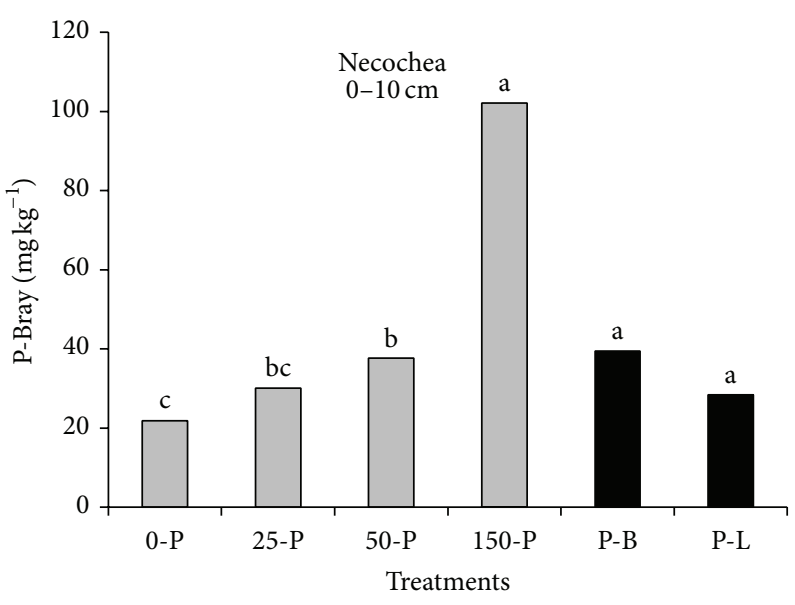

(b)

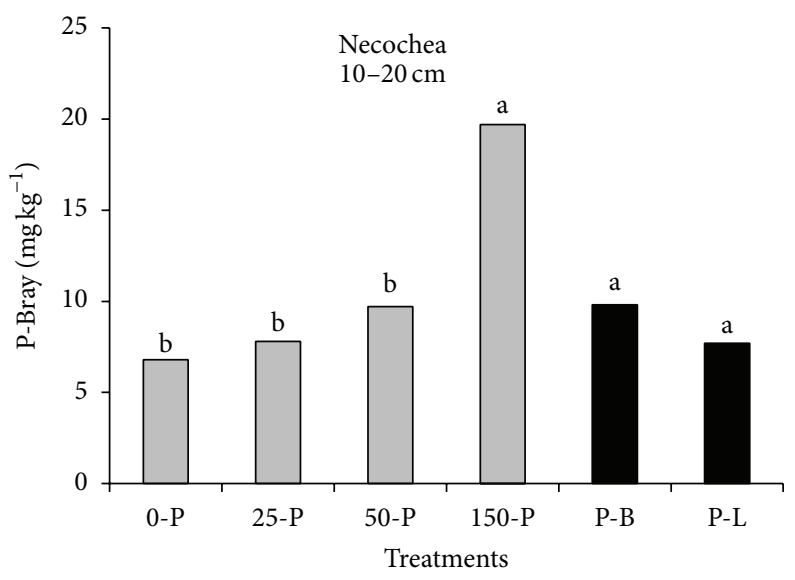

(d)

Figure 5: Available soil P-Bray at tillering ( $0-10$ and 10-20 cm) affected by placement method and P rate. Means followed by the same letter are not significantly different from each other based on the LSD test (0.05). Phosphorus response is compared using 25, 50, and 150 P rates (gray). Phosphorus placement method is only compared at 25 and 50 P rates. P-B: phosphorus broadcasted. P-L: phosphorus banded at sowing.

Covacevich et al. [37] showed that there was a negative relationship between AMC colonization of wheat roots (recovered both under field and glasshouse condition) and soil $\mathrm{P}$ availability at $0-20 \mathrm{~cm}$ of soil depth. At this experiment the AMC at the $0-20 \mathrm{~cm}$ depth of soil was also negatively correlated with available soil $\mathrm{P}\left(r^{2}=0.85, P=0.01\right)$. The mycorrhizal colonization was related to current available soil $\mathrm{P}$ through a unique function $\mathrm{AMC}=5.6+857.9 /(\text { Bray } \mathrm{P})^{2}$, both for fertilized (broadcasted and banded) and unfertilized treatments at the two phenological stages. The rate of decline in AMC was higher in the range of $6-13 \mathrm{mg} \mathrm{kg}^{-1}$ Bray$\mathrm{P}$, and decreased above this value. In general, at similar levels of soil P, values of AMC for broadcast P treatments were located above the trend line. This is another indication that broadcasted P decreased to a lesser extent the AMC in relation to line-banded applications. This could suggest more soil $\mathrm{P}$ uptake of root plants by banding but more mycorrhizal symbiosis uptake by broadcast $\mathrm{P}$ placement.

The extensive hyphal networks of AMF influence soil physicochemical properties and can directly or indirectly contribute to the release of soil $\mathrm{P}$ from inorganic complexes of low solubility [63]. In undisturbed soils, roots follow preformed channels, making close contact with the AMFinfected root system, resulting in enhanced AMC of the roots [21] and nutrient uptake. In Necochea, differences between $P$ placement and AMC were found although these were not statistically significant $(P>0.05)$. Plots with broadcast $\mathrm{P}$ had the highest available soil $\mathrm{P}$ and were always associated with high mycorrhizal development, mainly at tillering. It is probable that this has contributed to a high $\mathrm{P}$ uptake by roots with the consequent increase in plant growth. This may also partially explain the absence of differences in yield and plant $\mathrm{P}$ content between $\mathrm{P}$ placement treatments in latter stages of growth. AMC was recorded at only one-site, so that our results constitute only the beginning to understand possible contribution of mycorrhiza to accessibility of wheat roots to soil $\mathrm{P}$, especially under broadcast $\mathrm{P}$ applications.

Excess chemical fertilizer in soils is a major environmental concern and accumulation of $\mathrm{P}$ applied in excess can increase the risk of $\mathrm{P}$ movement to surface and groundwater [64]. Therefore, it is important that $\mathrm{P}$ management balances the goal of providing sufficient $\mathrm{P}$ to the crop to 


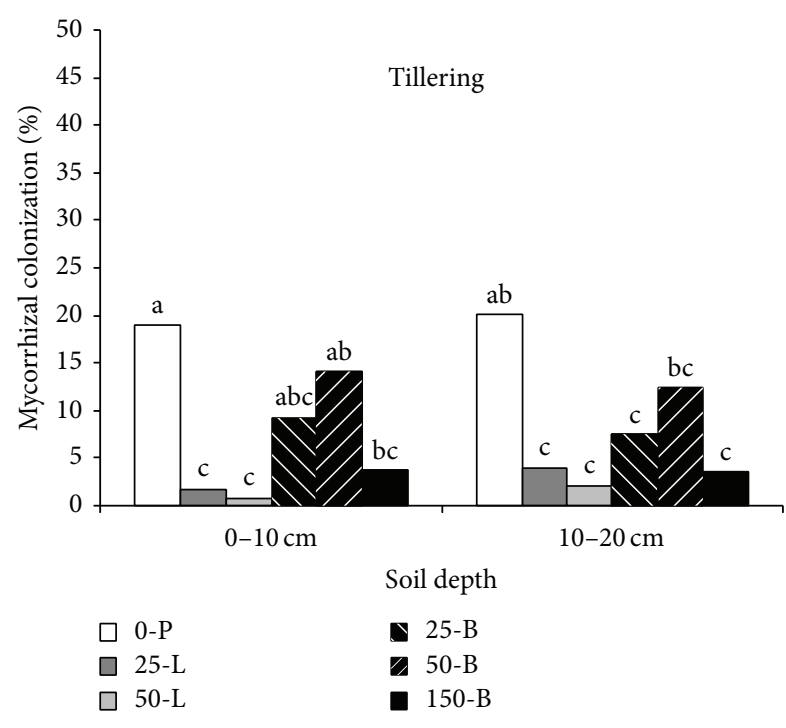

(a)

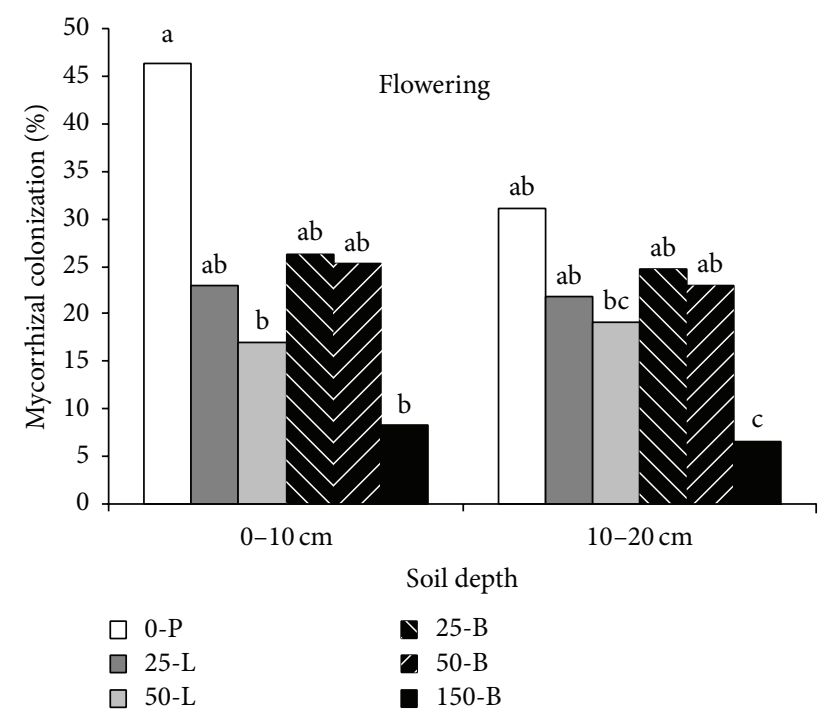

(b)

FIGURE 6: Indigenous mycorrhizal colonization of wheat roots at the Necochea site as affected by P fertilization and soil depth. Means followed by the same letter are not significantly different from each other based on the LSD test (0.05). P-B; phosphorus broadcasted. P-L: phosphorus banded at sowing.

optimize crop yield with the goal of avoiding excess $\mathrm{P}$ and environmental risk. Grant [65] pointed out that side banding of $\mathrm{P}$ could be better for crops (mainly in conditions with cold soil temperatures because of slower $\mathrm{P}$ diffusion rate). Moreover, she pointed out that in some cases mycorrhizal colonization could be detrimental to the plant (higher cost in photosynthesis than in $\mathrm{P}$ uptake benefit) because wheat seems to not be highly dependent on the mycorrhizal association to access soil $\mathrm{P}$ as a result of its extensive root development. However, for these conditions, our results are in disagreement with those reported by Grant [65]. It is probable that, without mycorrhiza formation, wheat plants in broadcast $\mathrm{P}$ treatments would be at a larger distance from the root system, which could limit the $\mathrm{P}$ availability to the root, in relation to $\mathrm{P}$ dep-banded adjacent to the seed. Thus, it is probable that high mycorrhiza formation, which was less depressed by the soil $\mathrm{P}$ in broadcasted treatments, aimed to connect the soil $\mathrm{P}$ with the roots allowing adequate access to nutrient. These results allow speculation that, under NT, the AMF could have functioned as "facilitators" of available soil P for wheat plants when $\mathrm{P}$ was broadcasted. Moreover banding $\mathrm{P}$ increased disturbance and could produce damage to the hyphal network reduce AMF growth and root colonization due to death or reduced infectivity of the hyphal fragments compared with intact networks and by detaching them from the host plants [21, 22]. However, the present study only provides the first steps in this direction and cannot confirm the possible mechanisms involved. Therefore, more comprehensive studies are needed to understand the contribution mycorrhiza to wheat associated with P placement.

\section{Conclusions}

These results indicate that in soils under NT with low available $\mathrm{P}$, high $\mathrm{OM}$ and water content in the surface horizon, $P$ placement method does not affect wheat grain yield, plant $\mathrm{P}$ uptake and recovery efficiency, independent of $\mathrm{P}$ rate. The lack of differences observed could be explained by a low $\mathrm{P}$ retention capacity in the soils where the research was conducted and maybe by a higher indigenous mycorrhiza formation in roots with applications of $\mathrm{P}$ broadcasted compared with P deep-banded.

\section{Conflict of Interests}

The authors declare that they have no conflict of interests regarding the publication of this paper.

\section{Acknowledgments}

This study was made possible by financial support of "Estado y dinámica de nutrientes del suelo" (PNSUELO1134024) project. Pablo Andrés Barbieri, Fernanda Covacevich, and Hernán René Sainz Rozas are grateful to CONICET, Argentina.

\section{References}

[1] A. J. Hall, M. Rebella, C. Ghersa, and J. P. Cullot, "Field-crop systems of the Pampas," in Field Crop Ecosystem, C. J. Pearso, Ed., pp. 413-450, Elsevier, Amsterdam, The Netherlands, 1992.

[2] M. A. Zárate, "Loess of southern South America," Quaternary Science Reviews, vol. 22, no. 18-19, pp. 1987-2006, 2003.

[3] R. Mendoza, "Application of the isotherms and interaction with soil and plant variables," Ciencia del Suelo, vol. 4, no. 2, pp. 117123, 1986.

[4] R. Mendoza and N. J. Barrow, "Characterizing the rate of reaction of some Argentinian soils whit phosphate," Soil Science, vol. 143, no. 2, pp. 105-112, 1987. 
[5] P. A. Calviño and V. O. Sadras, "On-farm assessment of constraints to wheat in relation to different previous crops," Journal Agriculture Science, vol. 118, pp. 157-163, 2002.

[6] INTA, Siembra directa, Actualización Técnica no. 58Febrero 2011, INTA Ministerio de Agricultura, Ganadería y Pesca, 2011, http://inta.gob.ar/documentos/siembra-directa/at_ multi_download/file/Siembra\%20Directa\%202011.pdf.

[7] P. A. Calviño, H. E. Echeverría, and M. Redolatti, "Estratificación de fósforo en el suelo y diagnóstico de la fertilización fosfatada en trigo en siembra directa," in Actas 17th Congreso Argentino de la Ciencia del Suelo Mar del Plata, p. 6, Actas en CD, April 2000.

[8] A. D. Halvorson, B. J. Wienhold, and A. L. Black, "Tillage, nitrogen, and cropping system effects on soil carbon sequestration," Soil Science Society of America Journal, vol. 66, no. 3, pp. 906912, 2002.

[9] A. Mozafar, T. Anken, R. Ruh, and E. Frossard, "Tillage intensity, mycorrhizal and nonmycorrhizal fungi, and nutrient concentrations in maize, wheat, and canola," Agronomy Journal, vol. 92, no. 6, pp. 1117-1124, 2000.

[10] J. W. Doran, "Soil microbial and biochemical changes associated with reduced tillage," Soil Science Society American Journal, vol. 44, no. 4, pp. 765-771, 1980.

[11] R. Qin, P. Stamp, and W. Richner, "Impact of tillage on root systems of winter wheat," Agronomy Journal, vol. 96, no. 6, pp. 1523-1530, 2004.

[12] S. A. Barber, "Effect of tillage practice on corn (Zea mays L.) root distribution and morphology," Agronomy Journal, vol. 63, no. 5, pp. 724-726, 1971.

[13] M. C. Fortin, "Soil temperature, soil water, and no-till corn development following in-row residue removal," Agronomy Journal, vol. 85, no. 3, pp. 571-576, 1993.

[14] R. Borges and A. P. Mallarino, "Grain yield, early growth, and nutrient uptake of no-till soybean as affected by phosphorus and potassium placement," Agronomy Journal, vol. 92, no. 2, pp. 380-388, 2000.

[15] E. A. Guertal, D. J. Eckert, S. J. Traina, and T. J. Logan, "Differential phosphorus retention in soil profiles under no-till crop production," Soil Science Society of America Journal, vol. 55, no. 2, pp. 410-413, 1991.

[16] P. Puget and R. Lal, "Soil organic carbon and nitrogen in a Mollisol in central Ohio as affected by tillage and land use," Soil and Tillage Research, vol. 80, no. 1-2, pp. 201-213, 2005.

[17] R. L. Fox and E. J. Kamprath, "Phosphate sorption isotherms for evaluating the phosphate requirements of soils," Soil Science Society of America Proceedings, vol. 34, no. 5, pp. 902-907, 1970.

[18] S. Schalamuk and M. Cabello, "Arbuscular mycorrhizal fungal propagules from tillage and no-tillage systems: possible effects on Glomeromycota diversity," Mycologia, vol. 102, no. 2, pp. 261268, 2010.

[19] Z. Kabir, I. P. O'Halloran, and C. Hamel, "Combined effects of soil disturbance and fallowing on plant and fungal components of mycorrhizal corn (Zea mays L.)," Soil Biology and Biochemistry, vol. 31, no. 2, pp. 307-314, 1999.

[20] T. P. Mcgonigle and M. H. Miller, "Development of fungi below ground in association with plants growing in disturbed and undisturbed soils," Soil Biology and Biochemistry, vol. 28, no. 3, pp. 263-269, 1996.

[21] D. G. Evans and M. H. Miller, "The role of the external mycelial network in the effect of soil disturbance upon vesiculararbuscular mycorrhizal colonization of maize," New Phytologist, vol. 114, no. 1, pp. 65-71, 1990.
[22] M. J. Goss and A. de Varennes, "Soil disturbance reduces the efficacy of mycorrhizal associations for early soybean growth and $\mathrm{N}_{2}$ fixation," Soil Biology \& Biochemistry, vol. 34, no. 8, pp. 1167-1173, 2002.

[23] Z. Kabir, I. P. O’Halloran, and C. Hamel, “Overwinter survival of arbuscular mycorrhizal hyphae is favored by attachment to roots but diminished by disturbance," Mycorrhiza, vol. 7, no. 4, pp. 197-200, 1997.

[24] A. B. Menéndez, J. M. Scervino, and A. M. Godeas, "Arbuscular mycorrhizal populations associated with natural and cultivated vegetation on a site of Buenos Aires province, Argentina," Biology and Fertility of Soils, vol. 33, no. 5, pp. 373-381, 2001.

[25] S. Schalamuk, S. Velazquez, H. Chidichimo, and M. Cabello, "Fungal spore diversity of arbuscular mycorrhizal fungi associated with spring wheat: effects of tillage," Mycologia, vol. 98, no. 1, pp. 16-22, 2006.

[26] O. P. Caviglia and F. H. Andrade, "Sustainable intensification of agriculture in the Argentinean pampas: capture and use efficiency of environmental resources," The Americas Journal Plant Science Biotechnology, vol. 3, no. 1, pp. 1-8, 2010.

[27] R. H. Bray and L. T. Kurtz, "Determination of total, organic and available form of phosphorus in soil," Soil Science, vol. 59, no. 1, pp. 360-361, 1945.

[28] F. O. García and A. Berardo, "Trigo," in Fertilidad de Suelos y Fertilización de Cultivos, H. Echeverría and F. García, Eds., pp. 233-253, INTA, Buenos Aires, Argentina, 2005.

[29] A. Berardo, F. D. Grattone, and G. A. Borrajo, "Efecto de la forma de aplicación del fósforo sobre la producción de trigo," in Actas del IV Congreso Nacional de Trigo y II Simposio Nacional de Cereales de Siembra Otoño-Invernal, pp. 25-27, Mar del Plata, Argentina, November 1998.

[30] F. Covacevich, H. R. Sainz Rozas, P. A. Barbieri, and H. E. Echeverría, "Formas de colocación de fósforo sobre el crecimiento y la micorrización espontánea del cultivo de trigo," Ciencia del Suelo, vol. 23, no. 1, pp. 39-45, 2005.

[31] J. M. Bordoli and A. P. Mallarino, "Deep and shallow banding of phosphorus and potassium as alternatives to broadcast fertilization for no-till corn," Agronomy Journal, vol. 90, no. 1, pp. 27-33, 1998.

[32] J. M. Bordoli, A. Quinke, and A. Marchessi, "Fertilización fosfatada de trigo en siembra directa," in Actas 18th Congreso Argentino de la Ciencia del Suelo, p. 6, Curitiba, Paraná, Junio de 2004.

[33] S. Asseng, J. T. Ritchie, A. J. M. Smucker, and M. J. Robertson, "Root growth and water uptake during water deficit and recovering in wheat," Plant and Soil, vol. 201, no. 2, pp. 265-273, 1998.

[34] Y.-G. Zhu, T. R. Cavagnaro, S. E. Smith, and S. Dickson, "Backseat driving? Accessing phosphate beyond the rhizospheredepletion zone," Trends in Plant Science, vol. 6, no. 5, pp. 194195, 2001.

[35] P. Jeffries and J. M. Barea, "Arbuscular mycorrhiza: a key component of sustainable plant- soil ecosystems," in Fungal Associations, B. Hock, Ed., pp. 95-113, Springer, Berlin, Germany, 2001.

[36] A. Schüßler, D. Schwarzott, and C. Walker, "A new fungal phylum, the Glomeromycota: phylogeny and evolution," Mycological Research, vol. 105, no. 12, pp. 1413-1421, 2001.

[37] F. Covacevich, H. E. Echeverría, and L. A. N. Aguirrezabal, "Soil available phosphorus status determines indigenous mycorrhizal colonization of field and glasshouse-grown spring wheat from Argentina," Applied Soil Ecology, vol. 35, no. 1, pp. 1-9, 2007. 
[38] J. A. Stecker, J. R. Brown, and N. R. Kitchen, "Residual phosphorus distribution and sorption in starter fertilizer bands applied in no-till culture," Soil Science Society of America Journal, vol. 65, no. 4, pp. 1173-1183, 2001.

[39] M. R. Hart, B. F. Quin, and M. L. Nguyen, "Phosphorus runoff from agricultural land and direct fertilizer effects: a review," Journal of Environmental Quality, vol. 33, no. 6, pp. 1954-1972, 2004.

[40] S. S. Malhi, C. A. Grant, A. M. Johnston, and K. S. Gill, "Nitrogen fertilization management for no-till cereal production in the Canadian Great Plains: a review," Soil and Tillage Research, vol. 60, no. 3-4, pp. 101-122, 2001.

[41] P. A. Barbieri, H. E. Echeverría, and H. R. Sainz Rozas, "Nitratos en el suelo a la siembra o al macollaje como diagnóstico de la nutrición nitrogenada en trigo en el sudeste bonaerense," Ciencia del Suelo, vol. 27, no. 1, pp. 41-47, 2009.

[42] J. C. Zadoks, T. T. Chang, and C. F. Konzak, "A decimal code for the growth stages of cereals," Weed Research, vol. 14, no. 6, pp. 415-421, 1974.

[43] J. M. Phillips and D. S. Hayman, "Improved procedures for clearing roots and staining parasitic and vesicular arbuscularmycorrhizal fungi for rapid assessment of infection," Transaction of the British Mycology Society, vol. 55, no. 1, pp. 158-161, 1970.

[44] A. Trouvelot, J. L. Kough, and V. Gianinazzi-Pearson, "Physiological and genetical aspects of mycorrhizae," in Proceedings of the 1st European Symposium on Mycorrhizae, V. GianinazziPearson, Ed., vol. 101, pp. 101-109, INRA, Paris, France, 1986.

[45] E. O. McLean, T. O. Oloya, and S. Mosthagimi, "Improved corrective fertilizer recommendations based on a two-step alternative usage of soil tests: I. Recovery of soil-equilibrated phosphorus," Soil Science Society of American Journal, vol. 46, no. 6, pp. 1193-1197, 1982.

[46] J. Murphy and J. P. Riley, "A modified single solution method for the determination of phosphate in natural waters," Analytica Chimica Acta, vol. 27, no. 1, pp. 31-36, 1962.

[47] R. W. Blanchar, G. Rehm, and A. C. Caldwell, "Sulfur in plant materials by digestion with nitric and perchloric acid," Soil Science Society of America Proceedings, vol. 29, pp. 71-72, 1965.

[48] Sas Institute, The SAS System Release 6.12 for Windows, SAS Institute, Cary, NC, USA, 1996.

[49] R. G. Allen, L. S. Pereira, D. Raes, and M. Smith, "Crop evapotranspiration-guidelines for computing crop water requirements," FAO Irrigation and Drainage Paper 56, FAOFood and Agriculture Organization of the United Nations, Rome, Italy, 1998.

[50] A. I. Della Maggiora, A. I. Irigoyen, J. M. Gardiol, O. P. Caviglia, and L. Echarte, "Evaluation of a soil water model for the wheat crop," Revista. Argricola de Agrometeorologia, vol. 2, no. 2, pp. 167-176, 2003.

[51] A. P. Mallarino, J. M. Bordoli, and R. Borges, "Phosphorus and potassium placement effects on early growth and nutrient uptake of no-till corn and relationships with grain yield," Agronomy Journal, vol. 91, no. 1, pp. 37-45, 1999.

[52] J. L. Falotico, G. A. Studdert, and H. E. Echeverría, "Nutrición nitrogenada del trigo bajo siembra directa y labranza convencional en condiciones de agricultura continua," Ciencia del Suelo, vol. 17, no. 2, pp. 15-27, 1999.

[53] A. D. Halvorson and J. L. Havlin, "No till winter wheat response to phosphorus placement and rate," Soil Science Society American Journal, vol. 56, pp. 1635-1639, 1992.
[54] A. Berardo, F. D. Grattone, and R. H. Rizalli, "Evaluación del efecto residual de fósforo en un Argiudol Típico bajo dos secuencias de cultivos," in Actas XIV Congreso Argentino de la Ciencia del Suelo, pp. 147-148, Mendoza, Argentina.

[55] C. A. Grant, D. N. Flaten, D. J. Tomasiewicz, and S. C. Sheppard, "The importance of early season phosphorus nutrition," Canadian Journal of Plant Science, vol. 81, no. 2, pp. 211-224, 2001.

[56] L. Lázaro and P. E. Abbate, "Deficiencias de fósforo como determinantes del número de granos en trigo," in Actas del V Congreso Nacional de Trigo, p. 6, Villa Carlos Paz, Córdoba, Spain, 2001.

[57] D. Rodríguez, W. G. Keltjens, and J. Goudriaan, "Plant leaf area expansion and assimilate production in wheat (Triticum aestivum L.) growing under low phosphorus conditions," Plant and Soil, vol. 200, no. 2, pp. 227-240, 1998.

[58] D. Rodríguez, F. H. Andrade, and J. Goudriaan, "Effects of phosphorus nutrition on tiller emergence in wheat," Plant and Soil, vol. 209, no. 2, pp. 283-295, 1999.

[59] F. Covacevich, H. R. Sainz Rozas, P. A. Barbieri, and H. E. Echeverría, "Crecimiento y micorrización arbuscular nativa de trigo en siembra directa bajo distintas formas de colocación de fósforo," Ciencia del Suelo, vol. 26, no. 2, pp. 169-175, 2008.

[60] M. Culleton and W. E. Murphy, "Distribution of phosphorus in soil," in Proceedings of the 10th Irish Environmental Researchers Colloquium, pp. 41-4100, The University of Ulster, Jordanstow, UK, 2000.

[61] E. Zamuner, L. I. Picone, and H. E. Echeverría, "Formas de fósforo en un suelo bajo labranza convencional y siembra directa," in Actas CD XIX Congreso Argentino de la Ciencia del Suelo, p. 6, AACS, Paraná, Brazil, 2004.

[62] L. I. Picone, E. G. Zamuner, A. Berardo, and M. A. Marino, "Phosphorus transformations as affected by sampling date, fertilizer rate and phosphorus uptake in a soil under pasture," Nutrient Cycling in Agroecosystems, vol. 67, no. 3, pp. 225-232, 2003.

[63] M. Parniske, "Arbuscular mycorrhiza: the mother of plant root endosymbioses," Nature Reviews Microbiology, vol. 6, no. 10, pp. 763-775, 2008.

[64] C. Grant, S. Bittman, M. Montreal, C. Plenchette, and C. Morel, "Soil and fertilizer phosphorus: Effects on plant P supply and mycorrhizal development," Canadian Journal of Plant Science, vol. 85, no. 1, pp. 3-14, 2005.

[65] C. A. Grant, "Supercharging your phosphorus fertilizer-does it work?" in Proceeding Manitoba Agronomist Conference, University of Manitoba, Winnipeg, Canada, December 2010.

[66] A. Walkley and I. A. Black, "An examination of Degtjareff method for determining soil organic matter and a proposed modification of the chromic acid titration method," Soil Science, vol. 37, no. 1, pp. 29-38, 1934. 


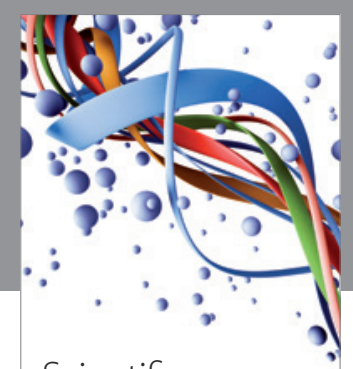

Scientifica
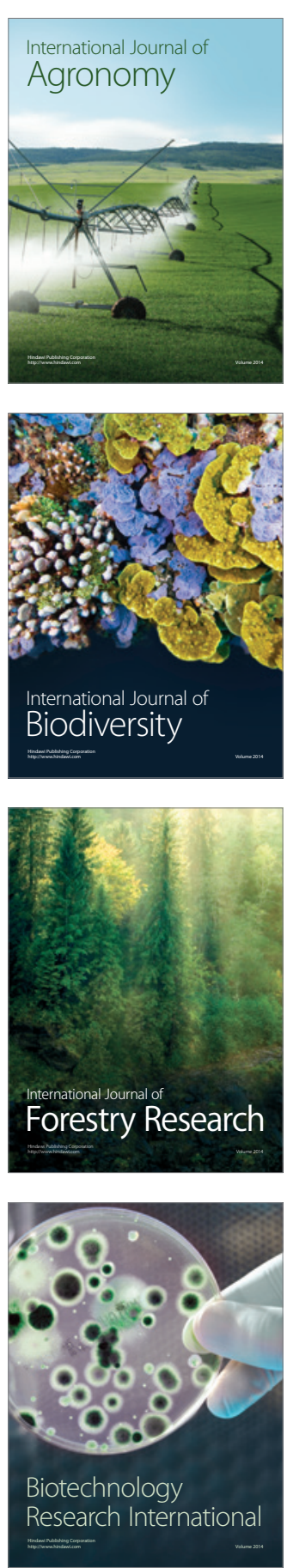
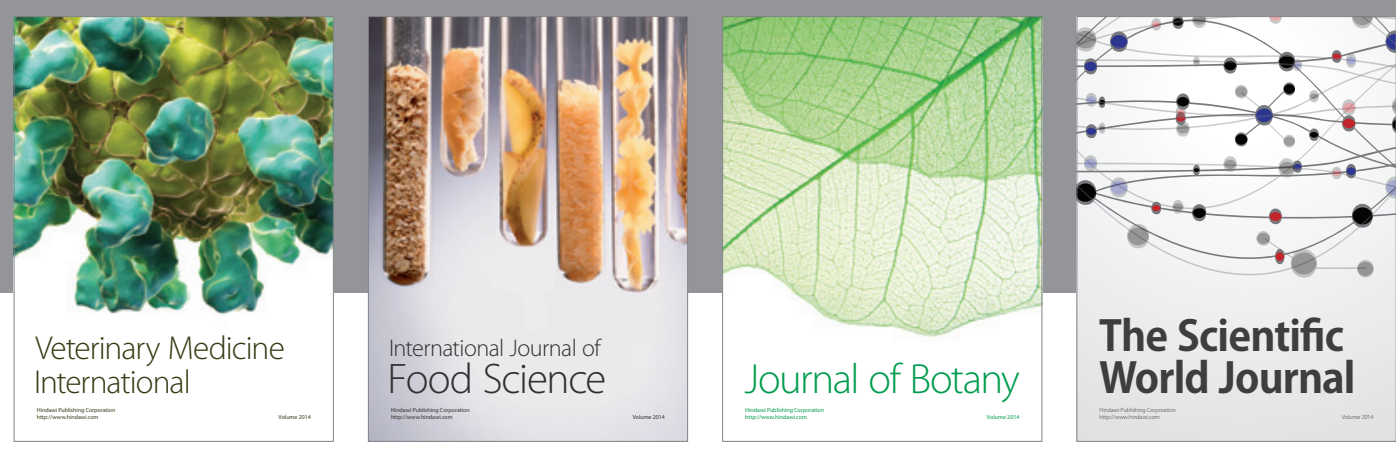

The Scientific World Journal
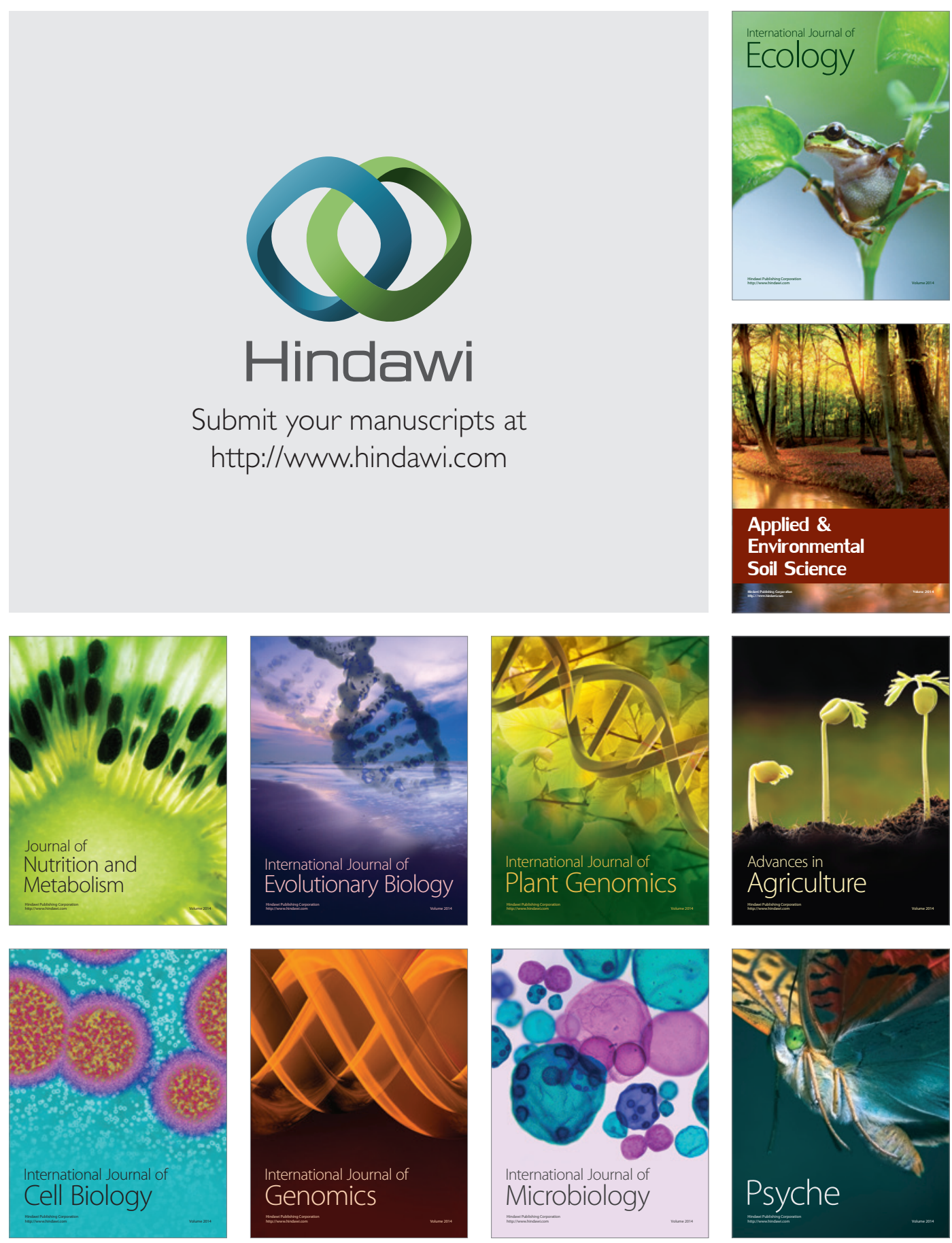